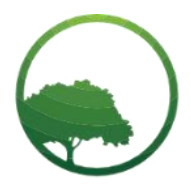

Research in Business \& Social Science

IJRBS VOL 10 NO 5 ISSN: 2147-4478

\title{
The influence of social media marketing activities on consumer engagement and brand knowledge in the culinary business in Indonesia
}

\author{
Khoirina Kencana Ningrum ${ }^{(a)}$ (iD) Ratna Roostika ${ }^{(b)}$ \\ (a) Master of Management Program, Islamic University of Indonesia (UII), Yogyakarta, Indonesia \\ (b) Senior Lecturer, Master of Management Program, Islamic University of Indonesia (UII), Yogyakarta, Indonesia
}

\author{
ARTICLE INFO \\ Article history: \\ Received 18 July 2021 \\ Received in rev. form 02 August 2021 \\ Accepted 04 August 2021 \\ Keywords: \\ Social Media Marketing, Consumer \\ Engagement, Brand Knowledge \\ JEL Classification: \\ $\mathrm{O} 15, \mathrm{P} 36$
}

\begin{abstract}
A B S T R A C T
This study aims to analyze the influence of elements of social media marketing activity on consumer engagement and brand knowledge including brand awareness and image. This study used a quantitative method and purposive sampling technique on 250 respondents. The research was conducted on all Indonesian citizens who use social media WhatsApp, Facebook, Instagram, YouTube, and TikTok regarding the culinary business of celebrities and YouTubers in Indonesia. The method used is the Structural Equation Model with AMOS 24.0 Software. The results of this study indicate that the interaction variables, trends, and EWOM have a positive and significant effect on consumer engagement, and consumer engagement has a positive and significant effect on brand awareness and brand image. While the entertainment and customization variables have no significant effect on consumer engagement.
\end{abstract}

(0) 2021 by the authors. Licensee SSBFNET, Istanbul, Turkey. This article is an open access article distributed under the terms and conditions of the Creative Commons Attribution (CC BY) license (http://creativecommons.org/licenses/by/4.0/).

\section{Introduction}

The needs of the people in Indonesia have increased, especially during the COVID-19 pandemic which is currently being experienced by the whole world, especially in Indonesia. The current pandemic has increased demand and the economy has declined. Competition in the business sector is increasing, because many are turning to their own business from home. Likewise, with public figures in Indonesia, such as celebrities and YouTubers who have started to open a culinary business by taking advantage of the development of social media in the midst of a pandemic like today. Many celebrities and YouTubers have started to open their culinary businesses by taking advantage of the development of social media in the midst of a pandemic like today. Some of the consumers will be curious and join in wanting to try because they see advertisements spread on social media for the sake of giving the impression that they have tried food or beverages from artists' brand.

The development of the internet in the community will make it easier for business people to distribute information and promote their products. According to data from the Central Statistics Agency (BPS) since the pandemic, the number of Internet users in Indonesia in early 2021 reached 202.6 million people. This number increased by $15.5 \%$ or 27 million people when compared to 2020 . The total population of Indonesia itself is currently 274.9 million people. This means that internet penetration in Indonesia will reach $73.7 \%$ in 2021. The increase in the number of internet users also has an impact on the increasing number of social media users. Through social media, several products can be found, such as clothing, cosmetics, to food and beverages that are included in the culinary industry. Consumers more often use various types of social media to find information about existing culinary and will grow the attraction to meet the food needs of each consumer. Social media that can be used such as Facebook, Instagram, WhatsApp, and

* Corresponding author. ORCID ID: 0000-0002-9172-0251

(C) 2021 by the authors. Hosting by SSBFNET. Peer review under responsibility of Center for Strategic Studies in Business and Finance. https://doi.org/10.20525/ijrbs.v10i5.1314 
TikTok which is currently going viral. Many entrepreneurs are driven by the ease and function of using social media in the culinary business sector as a means of promoting their products.

The culinary industry in Indonesia is also getting richer in terms of variants. In the current use of social media, consumers recognize the aesthetic appearance of food must have attractive, unique and aesthetic photos to upload to their respective social media so that other people are interested to see their profile. The emergence of new media has a great impact and influence on people's social life. Good communication strategies and techniques in implementing promotions using social media are needed for every culinary business today. This will affect the success or failure of a culinary business that is being run by the celebrity and YouTuber in Indonesia. According to Cheung et al., (2019) Social media marketing activities carried out will be formed from several elements, namely entertainment, interaction, trendiness, customization, and EWOM.

In the use of social media, of course, it requires the engagement of consumers in using social media. This consumer engagement will create and increase brand knowledge of a particular business. This can be used by businesses to tie consumers closer to a brand. Consumer engagement in the use of social media will be influenced by several elements of marketing activities carried out by each company. Given the potential of social media marketing activities, how to build consumer relationships with brands on social media has become an important issue for business people (Ismail, 2017; Liu et al., 2019; Prasad et al., 2017).

Seo \& Park (2018) said that in various literatures, social media marketing activities will have an impact on the formation of consumer brand knowledge. Brand knowledge in this case includes brand awareness and brand image which will ultimately be influenced by several elements. Promotions carried out by every business people using their various social media can provide benefits for consumer's brand awareness. In addition to increasing brand awareness of a product, the engagement of consumers in social media can improve brand image for the company. Consumers use social media anytime and anywhere easily and flexibly, through computers or mobile phones. Marketing strategy using social media will form and build a brand image through advertising, sales promotion, publications and public relations, personal selling, and direct marketing activities carried out by every business people.

Given the importance of what is described above, this study focuses on an integrative model that aims to examine the relationship between elements of social media marketing activity (entertainment, interaction, trendiness, customization, and EWOM), consumer engagement, brand awareness, and brand image in a business context. culinary celebrities and YouTubers, in Indonesia. This research is useful to contribute to research on social media activity. On the other hand, the research conducted can be taken into consideration in the formulation of policies and strategies. Especially with regard to the use of social media in marketing activities that will affect consumer engagement in the brand and its relationship with brand image and awareness of a brand.

Various fields and many studies on social media marketing activities, are still discussing and focusing more on the effects of social media marketing activities on customer satisfaction or consumer purchase intentions (Sano, 2015). It is still rare to discuss the influence of elements of social media marketing activities on consumer involvement in brands and their relationship to awareness and brand image of a product. This is what makes the writing of this research important to do. The purpose of this study was to determine the effect of social media marketing activities on consumer engagement and brand knowledge. The method that will be used in this research is a quantitative method with a sample of consumers who use social media.

\section{Literature Review}

\section{Theoretical Background and Conceptual Framework}

\section{Social Media Marketing}

In essence, social media is an internet-based technology that facilitates conversation. Social media reflects new sources of online information that are created, circulated, and used by consumers with the aim of educating each other about products, brands, services, personalities, and relevant issues that are currently happening. According to Cheung et al., (2019) social media has two interrelated promotional roles. First, social media allows companies to communicate with customers. Second, social media can be used by customers to communicate with other customers.

Kotler and Keller (2016) state that social media is a place for consumers to be able to share information in the form of text, images and videos related to a product, both among themselves and between consumers and companies or producers. There are many forms of social media that can be used by every user, including the most popular ones, namely Facebook, Instagram, WhatsApp, YouTube and TikTok. Of course, every social networking website has different services provided to users. This is a characteristic and also the advantages of each social networking website.Kim and Ko (2011) include activities on social media as part of entertainment, lifestyle and product promotion in the form of word of mouth communication. Conversations between customers provide companies with new ways to increase brand awareness, brand recognition and brand recall (Alves et al., 2016). According to Seo \& Park (2018), Social media marketing activities have several dimensions, namely as follows: Entertainment (Entertainment), Interaction (Interaction), Trendiness (Following the Trend), Customization (Customization), and EWOM (Electronic Word of Mouth).

\section{Entertainment}

Entertainment is the result of fun and games obtained through social media (Agichtein et al., 2008). Entertainment is an important component that drives follower behavior and response by creating positive emotions or feelings about the brand in the minds of 
followers on social media (Bilgihan, 2018). According to Cheung et al., (2019) Marketers use social media as a means to entertain consumers and to satisfy their need for pleasure, by sharing photos and direct information about products.

Entertainment activities, such as games, video sharing and participation in quizzes, can lead consumers to enjoy their experiences on social media, thereby motivating their participation in social media-based brand communities (Ashley and Tuten, 2015). Entertainment can build a close relationship between consumers and brands that are able to build awareness and image of a brand. Therefore, in the context of social media, entertainment represents the extent to which the social media platform offers interesting, impressive, and funny content and information to consumers (Gallaugher and Ransbotham, 2010).

\section{Interaction}

Interaction, according to Bilqin (2018), is a communication created by social media to get customer requests and needs, create opinions and suggestions about products and brands in real time. Interaction in social media marketing activities allows consumers to exchange experiences with other consumers regarding a particular brand (Cheung et al., 2019). Through this social media platform, it is possible to interact between consumers and consumers with businesses/companies. Through social media such as Facebook, Instagram, YouTube, WhatsApp, and TikTok, you can provide a notification to all followers or a subject quickly and continuously. Using social networks can create interactions using up-to-date broadcasting, and consumers can easily get information (Fischer \& Reuber, 2011).

\section{Trendiness}

Trendiness is defined as providing the latest information about a product or service (Bruno et al., 2016). Following trends as another component of social media marketing activities means introducing up-to-date product information to customers (Godey et al., 2016). The advertisements on this social media platform as a component refer to the advertising and promotion campaigns that businesses have carried out through social media to increase sales and develop customer portfolios. Trends are things that can influence consumer behavior in the lifestyle they want by growing brand knowledge in the minds of consumers.

\section{Customization}

Social media customization is a tool for companies to communicate their unique content about brands and can increase loyalty preferences to these brands (Martin and Todorov, 2010). Customization is carried out as a component of the customer satisfaction assessment provided based on business contacts with all other individual users (Seo \& Park, 2018). Businesses on social media can transfer the uniqueness of their products and brands to their customers through peer to peer communication. According to Bilqin (2018), the action component that creates customer satisfaction is based on business contacts with individual users. Customization is a consumer action to set the style that consumers like and follow current trends.

\section{EWOM}

EWOM is an exchange of service assessments among online users and a different concept from conventional WOM in many ways (Seo \& Park, 2018). WOM involves sharing experiences with others and may lead customer decision-making for buying or using the product or service (Wibowo \& Roostika, 2019). The existence of the internet creates a new paradigm in word of mouth communication and this is the beginning of the emergence of the term electronic word of mouth (EWOM). Electronic Word of Mouth (EWOM) as a response and commitment as well as an emotional response. One way to create consumer response in the form of EWOM is to increase brand knowledge which consists of brand image and brand awareness (Seo \& Park, 2018).

\section{Consumer Engagement}

Consumer engagement in a brand is an activity in which it indirectly involves related consumers to search, evaluate alternatives, and make decisions that involve brand selection (Vivek et al., 2012). In addition, according to Fung (2014) consumer engagement is physical, cognitive, and emotional engagement that will build relationships with the company. Consumer engagement in a brand is a concept that appears to see the emotional level of consumers and consumer behavior activities in their engagement with the brand (Cheung et al., 2019). Consumer engagement is an emerging concept in marketing in both practical and academic domains (France et al., 2016). The concept refers to the consumer's emotional level and behavioral activity in brand interactions and is seen as critical in influencing consumer behavioral engagement regarding a particular brand (Harrigan et al., 2017). De Vries et al., (2012) suggest that brands that are able to build brand knowledge on consumers have a positive influence on CBE, and are able to strengthen brand popularity.

\section{Brand Awareness}

Brand awareness is the ability of customers to recognize or recall a brand and associate it with a particular product category. Dimensions of brand awareness according to Kotler \& Keller (2016), namely 1) Brand Recognition is the ability of consumers to recognize the brand of a product or service that consumers have previously recognized and 2) Brand Recall is the ability of consumers to remember certain brands when looking for certain needs or being told certain types of products. Rapp \& Beitelspacher (2013) stated that consumers use social media to interact with friends, view photos, videos, and search for businesses and brands. 


\section{Brand Image}

Kotler \& Keller (2016) argues that a set of beliefs, ideas and impressions is defined as the image or image that a person has of an object where attitudes and impressions are strongly conditioned by the image or image of the object. This means that a person's beliefs, ideas and impressions have a very large influence on behavior and responses what they might do. A brand is a symbol of a company's superior product or a company logo to make it easier for consumers to recognize and remember the product or company.

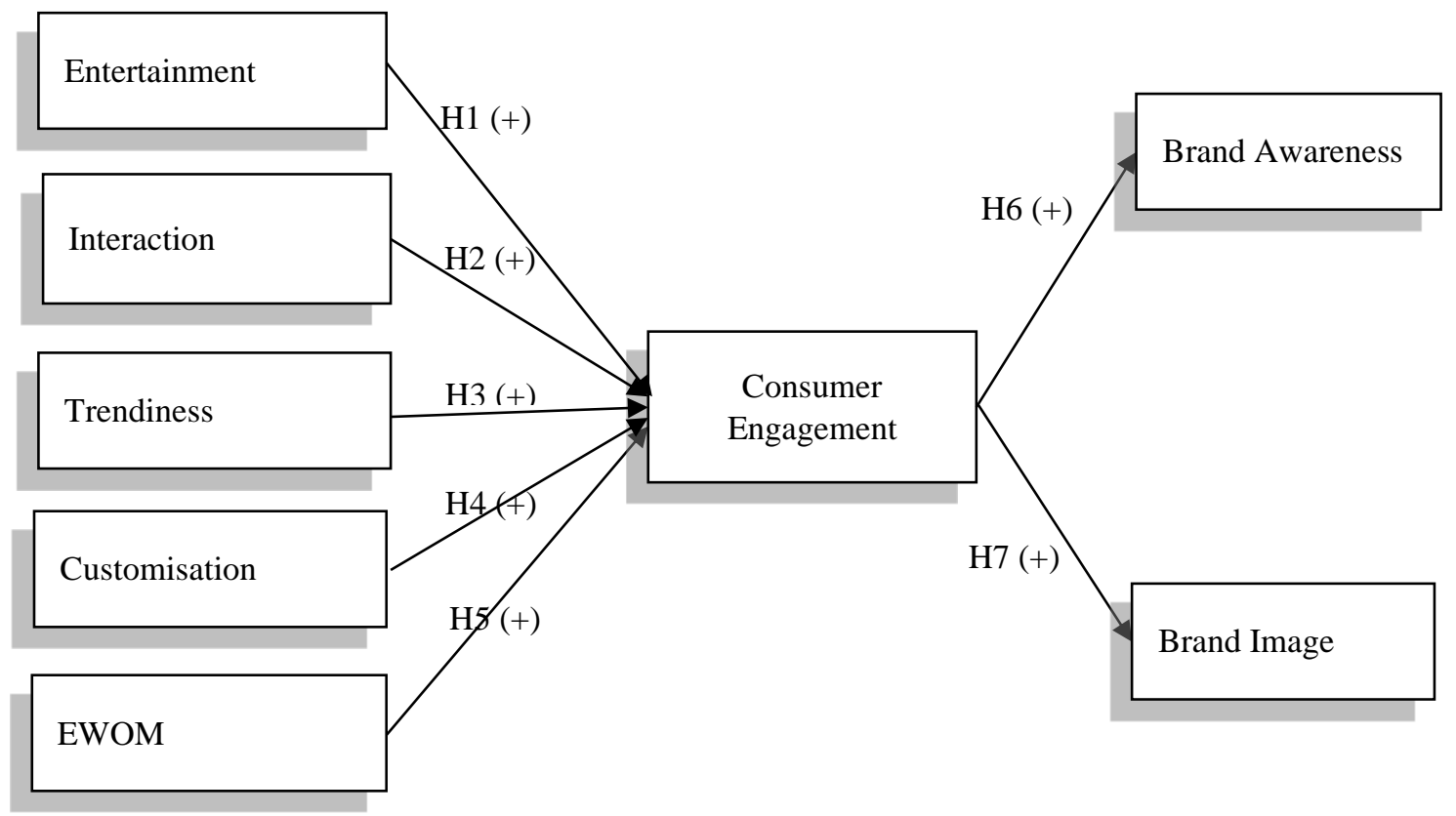

Figure 1: Conceptual Framework

\section{Empirical Review and Hypothesis development}

\section{Influence of Elements of Social Media Marketing Activities on Consumer Engagement}

The leading view of Consumer Engagement in the marketing domain is in championing the importance of interactive consumer experiences and consumer relationships on brands in building Consumer Engagement. Research conducted by Agichtein et al., (2008) and Ashley \& Tuten (2015) stated that the entertainment and interaction element is considered fun and has a positive effect on consumer engagement which encourages consumers to exert greater cognitive effort to understand more about the brand. Research conducted by Vivek et al., (2012); Leckie et al., (2016), and Ashley \& Tuten (2015) mention that consumer-brand interaction also helps brands with their new product development process, when consumers are active in sharing ideas and input related to products so as to increase consumer engagement in brand knowledge.

Trendy and up-to-date discussion topics available on fan pages of social media platforms will effectively attract more followers to engage in activities with other consumers in their work, thereby strengthening consumers' cognitive presence in brand-related interactions and helping to develop positive brand perceptions. Research conducted by Chan et al., (2014); Gallaugher \& Ransbotham (2010) and Dessart et al., (2015) stated that trendy information will help attract consumers' attention, generate positive feelings and be able to increase consumer engagement in a particular brand image and awareness. The above description is taken into consideration in building the following hypothesis:

Research conducted by Dehghani \& Tumer (2015) and Ismail (2017) stated that customization can strengthen the perceived value of brand pages and build consumer trust in brands so that the customization element in social media marketing activities is proven to have an influence on consumer engagement and arguably increases consumers' cognitive understanding of brand. The above description is taken into consideration in building the following hypothesis:

The effect of online branding shows that current buying is due to the strong role of EWOM in building brand image and brand awareness. Social media marketing allows companies to communicate easily and quickly with consumers. Research conducted by Chae et al., (2015) and De Vries et al., (2012), agrees that the availability of EWOM on social media platforms and its use helps in deepening consumer engagement with positive brand knowledge, thereby strengthening consumer and brand relationships. The above description is taken into consideration in building the following hypothesis:

H1: Elements of marketing activities (Entertainment) has a positive effect on consumer engagement.

H2: Elements of marketing activity (Interaction) has a positive effect on consumer engagement.

H3: Elements of marketing activity (Trendiness) have a positive effect on consumer engagement 


\section{H4: Elements of marketing activities (Customization) has a positive effect on consumer engagement.}

H5: Elements of marketing activity (EWOM) has a positive effect on consumer engagement.

Bruhn et al. (2012) said that the use of social media allows companies to increase their brand awareness. The use of social media adds to the attractiveness of a brand and increases the level of consumer intimacy with the brand. According to Kotler \& Keller (2016), the definition of brand awareness is the ability of consumers to identify brands under different conditions, as reflected by their brand recognition or perceived recall. This is in line with research conducted by Brodie et al., (2013) and Hanna et al., (2011) which stated that consumer engagement in a brand can affect the awareness of a particular brand. The above description is taken into consideration in building the following hypothesis:

\section{H6: Consumer engagement has a positive effect on brand awareness.}

Brands exist as a differentiator between one product and another, and to guarantee a certain quality. According to Kotler \& Keller (2016), the definition of brand image is the perception and belief made by consumers, as reflected in associations that occur in consumer memory. The research conducted by Chahal \& Rani, (2017) and Manthiou, et al (2016) stated that consumer engagement is able to affect the image of a brand in the eyes of consumers. The emotional attachment to the brand that is built through the process of consumer engagement promotes a strong and positive brand attitude, thereby strengthening the brand image. The above description is taken into consideration in building the following hypothesis:

\section{H7: Consumer engagement has a positive effect on brand image.}

\section{Research and Methodology}

\section{Population and Sample}

In this study, the population used is social media users. While the samples in this study were users of social media Facebook, Instagram, YouTube, WhatsApp, and TikTok to see the marketing activities of the culinary business of celebrities or YouTubers in Indonesia. The number of samples required is as many as 250 respondents. The method used to determine the sample in this study is non-probability sampling and sampling of respondents in this study is based on purposive sampling method. In conducting this research, the writer collects data through two methods, namely Questionnaire (Google Form) and literature study. The scale used in describing the value of the answers to the questions posed in this questionnaire uses 7 Likert scales. The Likert scale used is: $1=$ Strongly Disagree (STS); 2 = Disagree (TS); 3 = Disagree (KS); 4 = Neutral (N); 5 = Slightly Agree (US); $6=$ Agree (S); and $7=$ Strongly Agree (SS).

\section{Analysis Method}

This study uses SEM (Structural Equation Modeling) analysis using the AMOS 24 analysis tool. The first time the tested model can be modified by testing the standardized residuals that have been generated. The cut off value of 2.58 can be used to assess whether or not the residuals generated by the model are significant. The cut off value $>= \pm 2.58$ was interpreted as significant at the $5 \%$ level. This significant residual indicates a substantial prediction error for a pair of indicators. If it is more than the cut off value, then it needs to be modified.

According to Joreskog \& Sorborn (1993) Confirmatory Factor Analysis (CFA) a construct measurement model that cannot be measured directly, to test unidimensionality, validity, and reliability. Confirmatory Factor Analysis (CFA) is used to confirm or test a model. What is tested is the validity of indicators in a model. Validity test was conducted to determine the accuracy of the data collection tool or questionnaire. A questionnaire is said to be reliable if it is able to measure what should be measured through variable indicators. Construct validity consists of four types, namely Discriminant Validity, Convergent Validity, Construct Reliability and Variance Extracted. If the model is fit, we can evaluate each construct in two ways, namely by looking at the significance of the loading factor indicator or standardized regression weight estimate and through construct reliability and variance extracted. A good construct reliability value is above 0.70 while a good average variance extracted value is above 0.50 .

This study will explain the influence of the elements of social media marketing activities consisting of entertainment (HIB), interaction (INT), trendiness (TRE), customization (KUS), EWOM (EWO) on consumer engagement (KK) and brand knowledge. consists of brand awareness $(\mathrm{KM})$ and brand image $(\mathrm{CM})$ in the culinary business of celebrities and YouTubers in Indonesia. 
Table 1: Validity and Reliability Test

\begin{tabular}{|c|c|c|c|c|c|c|}
\hline Variable & Indicator & $\begin{array}{l}\text { Standard } \\
\text { Loading }\end{array}$ & Standard Load ${ }^{2}$ & Measurement Error & CR & VE \\
\hline \multirow{4}{*}{ HIB } & HIB4 & 0.751 & 0.564 & 0.436 & \multirow[t]{4}{*}{0.9} & \multirow{4}{*}{0.6} \\
\hline & HIB3 & 0.838 & 0.702 & 0.298 & & \\
\hline & HIB2 & 0.801 & 0.642 & 0.358 & & \\
\hline & HIB1 & 0.771 & 0.594 & 0.406 & & \\
\hline \multirow[t]{4}{*}{ INT } & INT4 & 0.777 & 0.604 & 0.396 & \multirow[t]{4}{*}{0.9} & \multirow[t]{4}{*}{0.7} \\
\hline & INT3 & 0.743 & 0.552 & 0.448 & & \\
\hline & INT2 & 0.888 & 0.789 & 0.211 & & \\
\hline & INT1 & 0.836 & 0.699 & 0.301 & & \\
\hline \multirow[t]{3}{*}{ TR } & TRE3 & 0.88 & 0.774 & 0.226 & \multirow[t]{3}{*}{0.8} & \multirow[t]{3}{*}{0.7} \\
\hline & TRE2 & 0.773 & 0.598 & 0.402 & & \\
\hline & TRE1 & 0.766 & 0.587 & 0.413 & & \\
\hline \multirow[t]{5}{*}{ KUS } & KUS4 & 0.819 & 0.671 & 0.329 & \multirow[t]{5}{*}{0.9} & \multirow[t]{5}{*}{0.6} \\
\hline & KUS5 & 0.756 & 0.572 & 0.428 & & \\
\hline & KUS3 & 0.821 & 0.674 & 0.326 & & \\
\hline & KUS2 & 0.792 & 0.627 & 0.373 & & \\
\hline & KUS1 & 0.805 & 0.648 & 0.352 & & \\
\hline \multirow[t]{3}{*}{ EWO } & EWO3 & 0.854 & 0.729 & 0.271 & \multirow[t]{3}{*}{0.8} & \multirow[t]{3}{*}{0.6} \\
\hline & EWO2 & 0.744 & 0.554 & 0.446 & & \\
\hline & EWO1 & 0.799 & 0.638 & 0.362 & & \\
\hline \multirow[t]{9}{*}{ KK } & CCP3 & 0.748 & 0.560 & 0.440 & \multirow[t]{9}{*}{0.9} & \multirow[t]{9}{*}{0.6} \\
\hline & CCP2 & 0.776 & 0.602 & 0.398 & & \\
\hline & CCP1 & 0.715 & 0.511 & 0.489 & & \\
\hline & CAF1 & 0.779 & 0.607 & 0.393 & & \\
\hline & CAF2 & 0.814 & 0.663 & 0.337 & & \\
\hline & CAF3 & 0.825 & 0.681 & 0.319 & & \\
\hline & CAC1 & 0.731 & 0.534 & 0.466 & & \\
\hline & CAC2 & 0.774 & 0.599 & 0.401 & & \\
\hline & CAC3 & 0.845 & 0.714 & 0.286 & & \\
\hline \multirow[t]{6}{*}{ KM } & KM1 & 0.793 & 0.629 & 0.371 & \multirow[t]{5}{*}{0.9} & \multirow[t]{5}{*}{0.7} \\
\hline & KM2 & 0.872 & 0.760 & 0.240 & & \\
\hline & KM3 & 0.854 & 0.729 & 0.271 & & \\
\hline & KM4 & 0.864 & 0.746 & 0.254 & & \\
\hline & KM5 & 0.825 & 0.681 & 0.319 & & \\
\hline & CM1 & 0.833 & 0.694 & 0.306 & \multirow[t]{7}{*}{0.9} & \multirow[t]{7}{*}{0.7} \\
\hline \multirow[t]{6}{*}{$\mathrm{CM}$} & CM2 & 0.823 & 0.677 & 0.323 & & \\
\hline & CM3 & 0.802 & 0.643 & 0.357 & & \\
\hline & CM4 & 0.856 & 0.733 & 0.267 & & \\
\hline & CM5 & 0.858 & 0.736 & 0.264 & & \\
\hline & CM6 & 0.87 & 0.757 & 0.243 & & \\
\hline & CM7 & 0.818 & 0.669 & 0.331 & & \\
\hline
\end{tabular}

From table 1 it is known that all indicators in this study already have a loading factor value of more than 0.5 , so it can be concluded that all indicators in this study are valid. From Table 4.10 it can also be seen that construct reliability (construct reliability) all variables have shown 0.7. As for the variance extracted in this study, each variable also has a value of 0.5 . So it can be concluded that the questionnaire used for this study was declared reliable.

\section{Result and Discussion}

The total number of questionnaires given to respondents was 262. Completely filled out questionnaires that could be used were 255 . Of the 255, they were checked again so that the amount of data used in the SEM analysis was 243. The study was conducted online, because the Covid-19 outbreak had not subsided, the research was conducted with the Google Form platform which is distributed through the WhatsApp and Instagram applications. Then testing with determine the model by connecting endogenous and exogenous latent constructs with indicator or manifest variables as shown in Figure. 


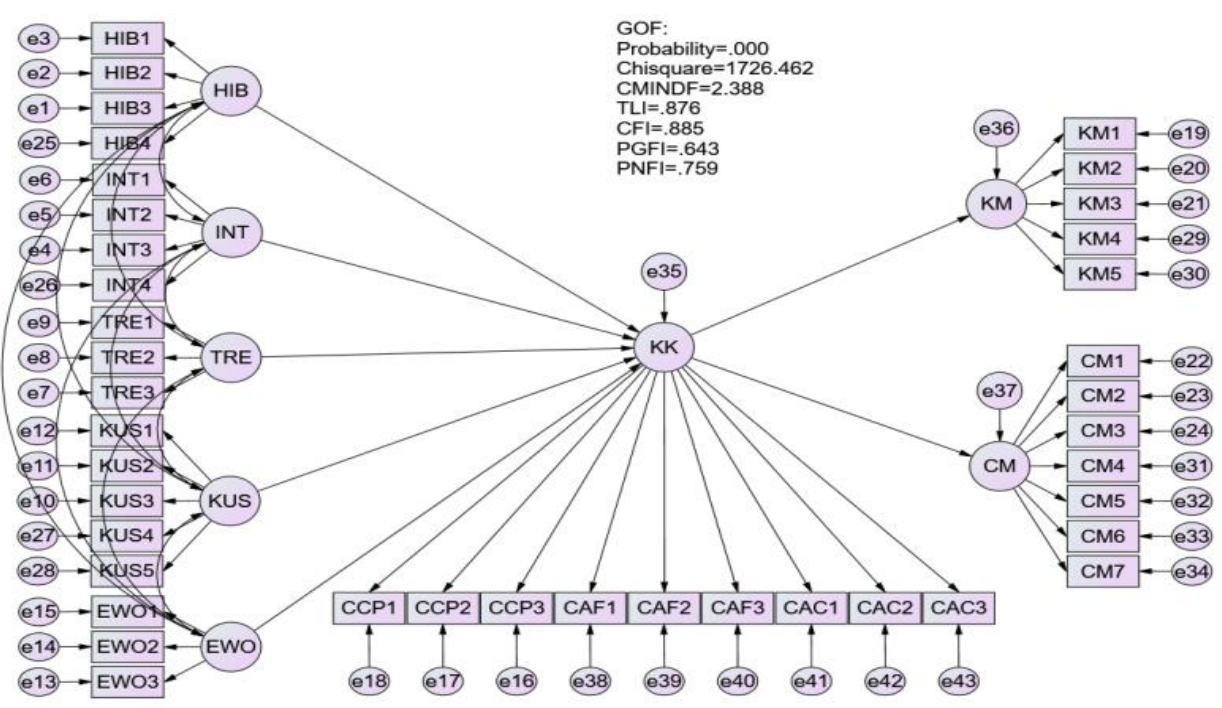

Figure 2: Diagram and path

\section{Normality Test}

This normality test is to observe the value of the Critical Ratio (CR) of the data used, if the multivariate data value is between the range of \pm 2.58 , the research data can be said to be normal. The results of the normality test showed the multivariate CR value is 1.937 , which means it is already between +2.58 and -2.58 . So that the data in this study can be said to be normally distributed.

The results show that the Goodness of Fit value has met all the criteria so that the model in this study can be said to be Fit as shown in the table.

Table 2: Value of Goodness of Fit

\begin{tabular}{|c|c|c|c|c|}
\hline Fit Index & Goodness of Fit & Criteria & Cut-off value & Information \\
\hline \multirow[t]{3}{*}{ Absolute Fit } & Chisquare & Small & 598.173 & Fit \\
\hline & Probability & $\geq 0.05$ & 0.056 & Fit \\
\hline & CMINDF & $\leq 2.00$ & 1.802 & Fit \\
\hline \multirow[t]{2}{*}{ Incremental Fit } & CFI & $\geq 0.90$ & 0.955 & Fit \\
\hline & TLI & $\geq 0.90$ & 0.941 & Fit \\
\hline \multirow[t]{2}{*}{ Parsimony Fit } & PGFI & $\geq 0.60$ & 0.628 & Fit \\
\hline & PNFI & $\geq 0.60$ & 0.692 & Fit \\
\hline
\end{tabular}




\section{Hypothesis Analysis}

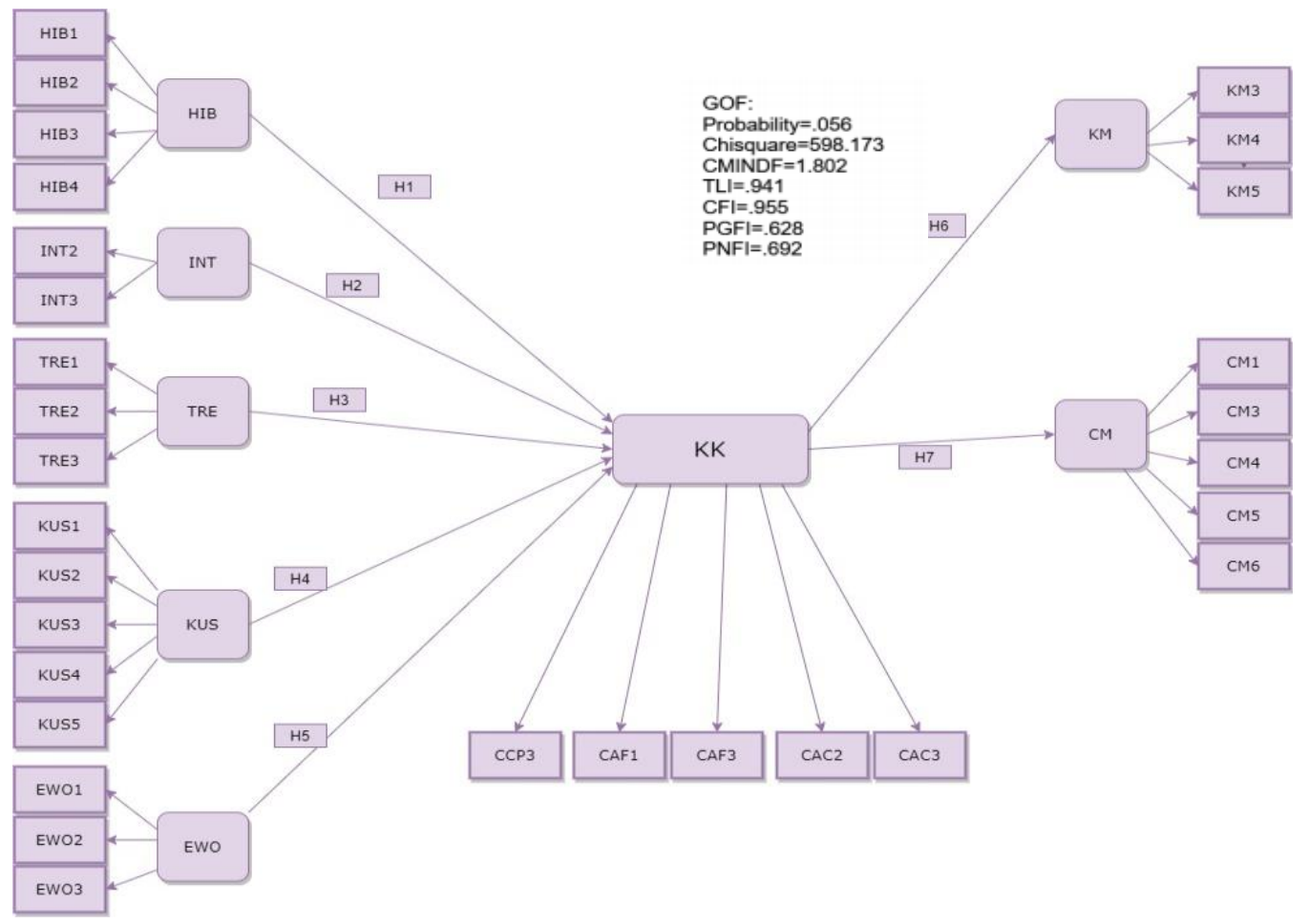

Figure 3: Hypothesis Analysis

Table 3: Regression weight test results

\begin{tabular}{|c|c|c|c|c|c|c|c|}
\hline & & & $\begin{array}{l}\text { Esti- } \\
\text { mate }\end{array}$ & SE & CR & $\mathbf{P}$ & Information \\
\hline $\begin{array}{l}\text { Consumer } \\
\text { Engagement }\end{array}$ & $<--$ & Entertainment & .148 & .217 & .681 & .496 & Not significant \\
\hline $\begin{array}{l}\text { Consumer } \\
\text { Engagement }\end{array}$ & $<--$ & Interaction & .210 & .102 & 2.059 & .039 & Significant Positive \\
\hline $\begin{array}{l}\text { Consumer } \\
\text { Engagement }\end{array}$ & $<--$ & Trendiness & .270 & -121 & 2.237 & .025 & Significant Positive \\
\hline $\begin{array}{l}\text { Consumer } \\
\text { Engagement }\end{array}$ & $<--$ & Customization & .037 & .277 & .134 & .893 & Not significant \\
\hline $\begin{array}{l}\text { Consumer } \\
\text { Engagement }\end{array}$ & <--- & EWOM & .345 & .134 & 2.568 & .010 & Significant Positive \\
\hline Brand Awareness & $<--$ & $\begin{array}{l}\text { Consumer } \\
\text { Engagement }\end{array}$ & 1.073 & .104 & 10.300 & .000 & Significant Positive \\
\hline Brand Image & $<--$ & $\begin{array}{l}\text { Consumer } \\
\text { Engagement }\end{array}$ & .994 & .109 & 9.084 & .000 & Significant Positive \\
\hline
\end{tabular}

The results of the analysis in Table 4 show that:

i. Entertainment has no significant effect on Consumer Engagement. This result is evidenced by a positive estimate value, a tstatistic value below 1.96 and a P-Value value above 0.05 . So H1 in this study is not supported.

ii. Interaction has a positive and significant effect on Consumer Engagement. This result is evidenced by a positive estimate value, a t-statistic value above 1.96 and a P-Value value below 0.05 . So that $\mathrm{H} 2$ in this study is supported.

iii. Trendiness has a positive and significant effect on Consumer Engagement. This result is evidenced by a positive estimate value, a t-statistic value above 1.96 and a P-Value value below 0.05 . So that $\mathrm{H} 3$ in this study is supported.

iv. Customization has no significant effect on Consumer Engagement. This result is evidenced by a positive estimate value, a t-statistic value below 1.96 and a P-Value value above 0.05 . So H4 in this study is not supported.

v. EWOM has a positive and significant effect on Consumer Engagement. This result is evidenced by a positive estimate value, a t-statistic value above 1.96 and a P-Value value below 0.05 . So that $\mathrm{H} 5$ in this study is supported. 
vi. Consumer Engagement has a positive and significant effect on Brand Awareness. This result is evidenced by a positive estimate value, a t-statistic value above 1.96 and a P-Value value below 0.05 . So that H6 in this study is supported.

vii. Consumer Engagement has a positive and significant effect on Brand Image. This result is evidenced by a positive estimate value, a t-statistic value above 1.96 and a P-Value value below 0.05 . So that $\mathrm{H} 7$ in this study is supported.

\section{Implications}

The analysis in this study was carried out using the Structural Equation Modeling (SEM) method using AMOS 24 software. Of the 7 hypotheses analyzed, it was found that the second, third, fifth, sixth, and seventh hypotheses were supported and the first and fourth hypotheses were not supported.

\section{Effect of Entertainment Marketing Activities on Consumer Engagement}

The results of the analysis in this study do not support the first hypothesis because the relationship between the elements of entertainment social media marketing activities and consumer engagement is not significant. These results contradict several previous studies by Dehghani \& Tumer (2015) and Ismail (2017), but there are also several studies that support the results of this study, namely Cheung et al., (2019) and Lim et al., (2017) which also found that elements of social media marketing activities entertainment has no significant effect on consumer engagement. The findings of the first hypothesis analysis in this study indicate that entertainment does not have such an important role in increasing consumer engagement in choosing social media to be used in finding information about culinary celebrities or YouTubers in Indonesia. Most consumers enjoy the entertainment available on social media, such as quiz games and picture videos just for refreshing. It cannot be ascertained that there is consumer engagement in determining which social media will be used to find information about the culinary business in Indonesia.

\section{Effect of Interaction Marketing Activities on Consumer Engagement}

The results of the analysis in this study support the second hypothesis which states that there is a positive and significant influence on the interaction elements of social media marketing activities on consumer engagement in the culinary business of celebrities and YouTubers in Indonesia. These findings are supported by several previous studies by Cheung et al., (2019); Vivek et al., (2012); Leckie et al., (2016); and Ashley \& Tuten (2015). The findings in this study indicate that the existence of interaction facilities in social media that makes it easier for consumers to communicate with other consumers is needed. Culinary business owners must pay attention to and develop interaction facilities in their business social media, because the better the interaction between consumers, the better the engagement of consumers in the culinary business. Interaction services in social media that need to be improved by celebgrams and YouTubers as culinary businessmen include, easy communication between consumers on social media, easy for consumers to exchange opinions on social media, and easy for consumers to express their hearts on social media.

\section{Effect of Trendiness Marketing Activities (Following Trends) on Consumer Engagement}

The results of the analysis in this study support the third hypothesis which states that there is a positive and significant influence of trendiness elements of social media marketing activities on consumer engagement in the culinary business of celebrities and YouTubers in Indonesia. These findings are supported by several previous studies, namely Seo and Park (2018); Miswanto and Angelia (2018); and Cheung et al., (2019), so it is increasingly evident that trends have an important role in increasing trust in consumer engagement. However, the results of this study also contradict other findings by Pomalaa, Mursityo, and Herlambang (2018). The results of the third hypothesis analysis prove that the existence of social media that is increasingly following the trend will have an important role in increasing consumer confidence in using social media so that it is not outdated which is growing. Culinary business owners must continue to develop existing facilities and services in social media so that they can always present the latest social media following current trends among the majority of consumers.

\section{Effect of Customization Marketing Activities on Consumer Engagement}

The results of the analysis in this study do not support the first hypothesis because the relationship between elements of customized social media marketing activities and consumer engagement is not significant. These results contradict several previous studies by Pomalaa, Mursityo, and Herlambang (2018); Seo and Park (2018); and Lim et al., (2017) but there are also several studies that support the results of this study, namely Cheung et al., (2019) which also found that the elements of customized social media marketing activities had no significant effect on consumer engagement. The findings of the fourth hypothesis analysis in this study indicate that customization does not have such an important role in increasing consumer engagement in using social media to be used in finding information about culinary celebrities or YouTubers in Indonesia. The phenomenon that exists in Indonesia itself, currently social media is growing and has various types. Consumers who enjoy it also certainly have their own desires and styles that cannot be realized directly in these social media services. The social media used by consumers only follows the style and model of the business owner/owner of the culinary business's social media account. This is because consumers do not directly feel the services provided by business people,

\section{Effect of EWOM Marketing Activities on Consumer Engagement}

The results of the analysis in this study support the fifth hypothesis which states that there is a positive and significant effect of elements of EWOM's social media marketing activities on consumer engagement in the culinary business of celebrities and 
YouTubers in Indonesia. These findings are supported by several previous studies by Pomalaa, Mursityo, and Herlambang (2018); Rizkiawan (2019); Chen and Lin (2019); Chae et al., (2015); and De Vries et al., (2012).

The findings in this study indicate that the elements of EWOM's social media marketing activities play an important role in consumer engagement in choosing social media to be used in making their choices in the culinary field. EWOM will play an important role because consumers read reviews or reviews of culinary products from other consumers via the internet, which in turn will encourage interest in purchasing the product or brand. Consumers will also be more motivated to make repeat purchases in the future and encourage consumers to provide product recommendations to other consumers. This will create confidence in consumers about the quality and benefits of these culinary products.

\section{Effect of Consumer Engagement on Brand Awareness}

The results of the analysis in this study support the sixth hypothesis which states that there is a positive and significant influence of consumer engagement on brand awareness in the culinary business of celebrities and YouTubers in Indonesia. These findings are supported by several previous studies, namely Bilgihan et al. (2019); Rizkiawan (2019); Brodie et al., (2013) and Hanna et al., (2011) so that it is increasingly proven that consumer engagement has an important role in growing brand awareness in a culinary business. However, the results of this study also contradict other findings, namely by Cheung et.al., (2019) which states that there is no significant influence of consumer engagement on brand awareness in the culinary business of celebrities and YouTubers in Indonesia.

The results of the analysis of the sixth hypothesis prove that the results of the study indicate that consumer engagement is one of the factors that influence consumer awareness of culinary business product brands in Indonesia. With increasing engagement, consumers have a greater motivation to pay attention, understand, and elaborate information about the purchase. Consumers will evaluate and compare the available brand options based on the value of each attribute. Based on the evaluation and comparison process, consumers can choose one of their brand choices.

\section{The Effect of Consumer Engagement on Brand Image}

The results of the analysis in this study support the seventh hypothesis which states that there is a positive and significant influence on brand image in the culinary business of celebrities and YouTubers in Indonesia. These findings are supported by several previous studies, namely by Chahal \& Rani, (2017) and Nguyen Van Thang et al., (2016) so that it is increasingly proven that consumer engagement has an important role in increasing trust in the brand image of a culinary business. However, the results of this study also contradict other findings, namely by Chen and Lin (2019) which state that there is no significant influence of consumer engagement on brand image in the culinary business of celebrities and YouTubers in Indonesia. Cheung et al., (2019) analyze no all consumer engagement has an effect on brand image.

The results of the seventh hypothesis analysis prove that consumer engagement has an effect on brand image. These results can be explained that consumer engagement in the use of social media to find information about culinary is the right step to improve the brand image of a culinary business belonging to celebrities and YouTubers in Indonesia. The advantages in marketing products through social media, among others, there are no limitations in time, place, and almost no use of fees are highly considered by consumers. Consumer engagement in this case, increasing is a very effective way to improve the brand image of a culinary business product belonging to celebrities and YouTubers.

\section{Conclusions}

This study analyzes 8 variables related to the use of social media marketing activities for the culinary business of celebrities and YouTubers in Indonesia, these variables include entertainment (HIB), interaction (INT), trendiness (TRE), customization (KUS), EWOM (EWO) on consumer engagement (KK) and brand knowledge consisting of brand awareness (KM) and brand image (CM). From the five variables, it was developed based on the theory and previous research into 7 hypotheses which were analyzed in this study. From the 7 hypotheses analyzed, it was found that the first, second, third and fourth hypotheses were supported and the fifth hypothesis was not supported.

From the results of the analysis in this study, the author recommends several implications of the findings to celebrities and YouTubers as culinary business owners. For celebrities and YouTubers who have culinary businesses in Indonesia, it is advisable to be able to form a marketing team in managing social media that is able to move consumers as marketing agents, namely through elements of social media marketing activities, especially interactions, following trends, and EWOM. Perhaps this can be formed through the provision of good reviews or reviews on social media and recommendations by consumers to those around them.

Celebrities and YouTubers who have culinary businesses in Indonesia are expected to be able to do social media marketing well, complementing marketing instruments with well-managed social media because it is proven to be able to foster consumer engagement which later consumer engagement can increase brand awareness and brand image of a business. culinary business run by businessmen.

The limitation in this study is that it still does random sampling so it cannot be ascertained that the respondents in this study have the same level both economically and geographically. This study is still analyzing consumer engagement and brand knowledge with 
limited variables, namely elements of social media marketing activities such as entertainment, interaction, following trends, customization, and EWOM.

Furthermore, the respondents in this study are still limited to consumers who use social media, have not specifically used social media to view information about the culinary business of celebgrams or YouTubers, so most people still do not understand the culinary business of celebgrams and YouTubers in Indonesia

For further research, it is recommended to expand the scope of research and compare or combine other variables in an effort to increase consumer engagement and brand knowledge. Further research is also expected to be able to develop measurement of variables both elements of entertainment marketing activities, interaction, trendiness, customization, and EWOM. Future research is also expected to be able to combine analytical methods, namely using mixed methods by complementing quantitative findings with qualitative findings

\section{References}

Agichtein, E., Castillo, C., Donato, D., Gionis, A. and Mishne, G. (2008), Finding high-quality content in social media. Proceedings of the 2008 International Conference on Web Search and Data Mining, Association for Computing Machinery(ACM), New York, 183-194. https://doi.org/10.1145/1341531.1341557.

Alves, H., Fernandes, C., Raposo, M., 2016. Social media marketing: a literature review and implications. Psychol. Mark. 33 (12), 1029-1038.

Ashley, C. and Tuten, T. (2015). Creative strategies in social media marketing: an exploratory study of branded social content and consumer engagement. Psychology and Marketing, 32, 1, 15-27.

Bilgihan et al., (2019). Brand Awareness, Image, Physical Quality and Employee Behavior as Building Blocks of Customer-Based Brand Equity: Consequences in the Hotel Context. Journal of Hospitality and Tourism Management. Vol 40. 114-124.

Bilqin, Y. (2018). The Effect Of Social Media Marketing Activities On Brand Awareness, Brand Image And Brand Loyalty. Business \& Management Studies: An International Journal, 6(1), 128-148.

Brodie, R.J., Ilic, A., Juric, B. and Hollebeek, L. (2013). Consumer engagement in a virtual brand community: an exploratory analysis. Journal of Business Research, 66, 1, 105-114.

Brodie, R., Hollebeek, L., Juri_c, B. and Ili_c, A. (2011). Customer engagement: conceptual domain, fundamental propositions, and implications for research. Journal of Service Research, 14, 3, 252-271.

Bruhn, M., Schoenmueller, V. and Sch€afer, D.B. (2012). Are social media replacing traditional media in terms of brand equity creation?. Management Research Review, 35, 9, 770-790.

Bruno, G., Aikaterini, M., Daniele, P., Joonas, R., Gaetano, A., Raffaele, D., Rahul, S., (2016). Social media marketing efforts of luxury brands: influence on brand equity and consumer behavior. J. Bus. Res. 69 (12), 5833-5841.

Cahyo, P.W. and Roostika, R. (2019) Building Positive Word-of-Mouth in the Shopping Tourism. Review of Integrative Business and Economics Research, 8(s4), 372-386.

Central Bureau of Statistics (BPS), Central Jakarta, 2021. Statistics of Indonesia Internet Users in 2021. Jakarta.

Center : Central Bureau of Statistics

Chan, TK, Zheng, X., Cheung, CM, Lee, MK and Lee, ZW (2014). Antecedents and consequences of customer engagement in online brands.

Chae, H., Ko, E. and Han, J. (2015). How do customers' SNS participation activities impact on customer equity drivers and customer loyalty? Focus on the SNS services of a global SPA brand. Journal of Global Scholars of Marketing Science, 25, 2, $122-141$.

Chahal, H. and Rani, A. (2017). How trust moderates social media engagement and brand equity. Journal of Research in Interactive Marketing, 11, 3, 312-335.

Cheung, Man Lai., Pires, Guilherme., Rosenberger, Philip. (2019). The Influence of Perceived Social Media Marketing Elements on Consumer-Brand Engagement and Brand Knowledge. Asia Pacific Journal of Marketing and Logistics, 32, 3, 695-720. Emerald Publishing Limited. DOI:10.1108/APJML-04-2019-0262

De Vries, L., Gensler, S. and Leeflang, P.S. (2012). Popularity of brand posts on brand fan pages: an investigation of the effects of social media marketing. Journal of Interactive Marketing, 26, 2, 83-91.

De Vries, N. and Carlson, J. (2014). Examining the drivers and brand performance implications of customer engagement with brands in the social media environment. Journal of Brand Management, 21, 6, 495-515.

Dehghani, M. and Tumer, M. (2015). A research on effectiveness of Facebook advertising on enhancing purchase intention of consumers. Computers in Human Behavior, 49, 597-600.

Dessart, L., Veloutsou, C. and Morgan-Thomas, A. (2015). Consumer engagement in online brand communities: a social media perspective. The Journal of Product and Brand Management, 24, 1, 28-42.

Fischer, E. and Reuber, AR (2011). Social interaction via new social media: (How) can interactions on Twitter affect effectual thinking and behavior?. Journal of Business Ventures, 26, 1, 1-18.

France, C., Merrilees, B. and Miller, D. (2016). An integrated model of customer-brand engagement: drivers and consequences. Journal of Brand Management, 23, 2, 119-136.

Gallaugher, J. and Ransbotham, S. (2010). Social media and customer dialog management at Starbucks. MIS Quarterly Executive, $9,4,197-212$. 
Godey, B., Manthiou, A., Pederzoli, D., Rokka, J., Aiello, G., Donvito, R., \& Singh, R. (2016). Social media marketing efforts of luxury brands: Influence on brand equity and consumer behavior. Journal of Business Research. 69(12), 5833-5841.

Haenlein, M. and Kaplan, A.M. (2004). A beginner's guide to partial least squares analysis. Understanding Statistics, 3, 4, $283-297$. Hair et al., (1998), Multivariate Data Analysis, Fifth Edition. Prentice Hall. UpperSaddle River : New Jersey.

Hair et al., (2010). Multivariate Data Analysis (7th ed). United States : Pearson

Hanna, R., Rohm, A. and Crittenden, V.L. (2011). We're all connected: the power of the social media ecosystem. Business Horizons, $54,3,265-273$.

Harrigan, P., Evers, U., Miles, M. and Daly, T. (2017). Customer engagement with tourism social media brands. Tourism Management, 59, 597-609.

Harrigan, P., Evers, U., Miles, M.P. and Daly, T. (2018). Customer engagement and the relationship between engagement, engagement, self-brand connection and brand usage intent. Journal of Business Research, 88, 388-396.

Ismail, A.R. (2017). The influence of perceived social media marketing activities on brand loyalty: the mediation effect of brand and value consciousness. Asia Pacific Journal of Marketing and Logistics, 29, 1, 129-144.

Kaplan, A.M. and Haenlein, M. (2010). Users of the world, unite! the challenges and opportunities of Social Media. Business Horizons, 53, 1, 59-68.

Joreskog, K.G. \& Dag Sorborn. (1993). LISREL 8 : Structural Equotion Modelingwith the Simples Command Language. Chicago : Scientic Software International Inc.

Kim, AJ, \& Ko, E. (2012). Do Social Media Marketing Activities Enhance Customer Equity? An Empirical Study of Luxury Fashion Brands. Journal of Business Research, 65(10), 1480-1486.

Kotler, Philip, and Armstrong. (2009). Pearson's Principles of Marketing. In Pearson.

Kotler, P., \& Keller, KL (2016). Marketing Management. In Pearson Edition Limited.

Leckie, C., Nyadzayo, M. and Johnson, L. (2016). Antecedents of consumer brand engagement and brand loyalty. Journal of Marketing Management, 32 Nos 5-6, 558-578.

Lim, XJ, Radzol, AM, Cheah, J., \& Wong, MW (2017). The impact of social media influencers on purchase intention and the mediation effect of customer attitude. Asian Journal of Business Research, 7(2), 19-36

Liu, B. F., Jin, Y., Briones, R., and Kuch, B., (2019). Managing turbulence in the blogosphere: Evaluating the blog-mediated crisis communication model with the American red-cross. Journal of Public Relations Research, 24,, 4, 353-370.

Manthiou, A., Rokka, J., Godey, B. and Tang, L.R. (2016). How social media marketing efforts influence brand equity creation and its consequences: the case of luxury brands in Obal, M., Krey, N., Bushardt, C. (Eds), Let's Get Engaged! Crossing the Threshold of Marketing's Engagement Era, Developments in Marketing Science: Proceedings of the Academy of Marketing Science, Springer, Cham.

Martin, K. and Todorov, I. (2010). How will digital platforms be harnessed in 2010, and how will they change the way people interact with brands?. Journal of Interactive Advertising, 10, 2, 61-66.

Miswanto \& Angelia Y.R. (2018). The Influence of Customer Satisfaction on Trust, Word of Mouth, and Repurchase Intention Case for Consumer of Souvenir Stores in Yogyakarta. ICEBM, 308-313.

Nguyen Van Thang, L., Conduit, J., Nguyen Hong Hai, D. and Nguyen, H. (2016). The impact of social media engagement on customer brand perception: the mediating effect of electronic word-of-mouth. ANZMAC 2016: Marketing in PostDisciplinary Era, University of Canterbury, New Zealand, 351-358.

Prasad, S., Garg, A. and Prasad, S. (2019). Purchase decision of generation Y in an online environment. Marketing Intelligence and Planning, 37, 4, 372-385.

Prasad, S., Gupta, I.C. and Totala, N.K. (2017). Social media usage, electronic word of mouth and purchase-decision engagement. Asia-Pacific Journal of Business Administration, 9, 2, 134-145.

Rapp, A., Beitelspacher, L., Grewal, D., Hughes, D., (2013). Understanding social media effects across seller, retailer, and consumer interactions. J. Acad. Mark. Sci. 41 (5), 547-566.

Seo, EJ, \& Park, JW (2018). A study on the effects of social media marketing activities on brand equity and customer response in the airline industry. Journal of Air Transport Management, Vol 66. pp. 36-41.

Vivek, S., Beatty, S. and Morgan, R. (2012). Customer engagement: exploring customer relationships beyond purchase. Journal of Marketing Theory and Practice, 20, 2, 122-146.

Publisher's Note: SSBFNET stays neutral with regard to jurisdictional claims in published maps and institutional affiliations.

\section{(9) (1)}

(C) 2021 by the authors. Licensee SSBFNET, Istanbul, Turkey. This article is an open access article distributed under the terms and conditions of the Creative Commons Attribution (CC BY) license (http://creativecommons.org/licenses/by/4.0/).

International Journal of Research in Business and Social Science (2147-4478) by SSBFNET is licensed under a Creative Commons Attribution 4.0 International License. 